Available Online at http://journal.unismuh.ac.id/index.php/otoritas

Otoritas : Jurnal Ilmu Pemerintahan, 7 (2), October 2017, 84-92

\title{
An Ethical Investigation of State and the Management of Internally Displaced Persons in Nigeria
}

\author{
Ifeanyichukwu Micheal Abada1, Nneka Ifeoma Okafor ${ }^{2 *}$ ) \\ ${ }_{1}^{1}$ Department of Political Science, Faculty of Social Sciences, University of Nigeria, Nsukka Road, \\ 410001, Nsukka, Nigeria. \\ ${ }^{2}$ Department of Philosophy, Faculty of Social Sciences, University of Nigeria, Nsukka Road, 410001, \\ Nsukka, Nigeria.
}

Received: 29 September 2017; Revised: 10 October 2017; Accepted: 28 October 2017

\begin{abstract}
The spontaneous displacement and wandering of men had always been propelled by the forces of nature and other anthropogenic activities. Man, as a rational being had remained strategical for their survival. The upsurge in the activities of Boko Haram in Nigeria, north east occasioned by their clientele interests had necessitated decisions by men to forcefully relocate their places of abode. However, the purpose of the study is to ethically investigate whether the ineffective curtailment of the activities of Boko Haram had implicated the increasing vulnerabilities of internally displaced persons. The study utilized qualitative method in generating its data, while the theoretical framework was adequately anchored on the Marxist theory of the post-colonial state. The findings of the study had significantly revealed that the ineffective management of Boko Haram menace by the state had implicated the rising vulnerabilities of internally displaced persons. However, the study recommends among other things, the integration of relevant commission and prosecution of personalitycults engage in sabotaging the efforts of the state.
\end{abstract}

Keywords: Boko Haram Insurgency; Ethics; Humanitarian Crisis; Internally Displaced Persons

How to Cite: Abada, I. M., \& Okafor, N. I. (2017). An Ethical Investigation of State and the Management of Internally Displaced Persons in Nigeria. Otoritas : Jurnal Ilmu Pemerintahan, 7(2), 84-92.

Permalink/DOI: https://doi.org/10.26618/ojip.v7i2.889

${ }^{*}$ Corresponding Author.

E-Mail : nefo202@yahoo.com

Copyright (C) 2017, Otoritas : Jurnal Ilmu Pemerintahan, ISSN: 2088-3706 (Print), ISSN: 2502-9320 (Online) 
Available Online at http://journal.unismuh.ac.id/index.php/otoritas

Otoritas : Jurnal Ilmu Pemerintahan, 7 (2), October 2017, 85

\section{INTRODUCTION}

A major herculean task facing the Nigerian government from 2009 is the technicality in combating the Boko Haram insurgency in the country, mostly in the North-Eastern part of the country. The degeneration of the conflict into an armed insurgency is implicated on the rise of humanitarian aid as lots of people under threats in the North East had to flee their homes for safety. Since Boko Haram insurgents started their campaign of terror against the Nigerian state in the Northeast, many lives have been lost while properties worth millions of destroyed.

However, between 2009 and 2017, Boko Haram had attacked and targeted a variety of groups including Christians, traditional rulers, politicians, school children and teachers, Islamic scholars, public servants, traders and lately all nonmembers of the group (SFCG and World Bank, 2014). In a bid to protect oneself and family, from the Boko Haram threats, who have proved to become an insurmountable obstacle, people of the region began to flee their homes to neighboring towns and villages as the insurgency continues to prevail.

However, taking a sympathetic stance, the number of internally displaced people is on the increase as empirical assessment indicates that 13.33 per cent were displaced due to communal clashes, 0.99 per cent by natural disasters and 85.68 per cent because of insurgency attacks by Islamists, and there are 2,241, 484 internally displaced persons (IDPs) in Nigeria (International Organization for Migration, 2016). This alarming statistic is more damning given that the displaced persons are susceptible to vulnerabilities as access to education, health services, employment, economic activities etc becomes difficult.

The 2014 report of the National Emergency Management Agency (NEMA) indicates that over 9 million people have been indirectly affected by the Boko Haram insurgency while over 3 million others are directly affected and in dire need of humanitarian relief assistance across Nigeria. The point here is that there is higher number of IDPs because of insurgency (attacks by the Boko Haram) than any other cause of internal displacement of persons. Also in 2014, the United Nations (UN) reports that an estimated 14.9 million IDPs were in about 26 countries all over the world with about 4.4 million of them found in Northern Nigeria. But it is pertinent to note that Nigerian had always been bedevilled with incessant conflicts, arising to high incidence of IDPs.

Obikaeze \& Onuoha (2016) traces it that historically, the country has often experienced incidences or crises leading to the displacement of people from their original inhabitations. For instance, the civil war that took place in Nigeria between 1967 and 1970 resulted to the displacement of people especially those from the Eastern region of the country. Intraethnic conflicts, flooding, erosion, desert encroachment among others has remained a great challenge facing the country. Sometimes the causes of displacement are complex and often overlapping.

For Ladan (2011), he argues that in Nigeria, most of the incidences of internal displacement occur because of violent conflicts with ethnic religious and/or political sentiments. He futher opines that thousands are annually internally displaced because of natural disasters including flooding in the North and West, erosion in the East, oil spillage and development projects in the Niger Delta (South -South) but he concluded that the Boko Haram insurgency has the highest number of IDPs as a result of her armed violence.

However, the management of IDPs by the State has remained a tough issue to various administrations in Nigeria. The rehabilitation and resettlement of IDPs in Nigeria as well as provision of adequate 
security for IDPs have posed a bid challenge to the Nigerian State despite claimed efforts of national authorities to achieve this goal. The multiplier effect of the above circumstance is an indicator that if Boko Haram insurgency remains uncontrolled and unabated, the management of the IDPs by the state will continue to soar ineffectively. This is because of varied interests of personalities or groups taking the advantages of the humanitarian aides to ventilate their selfish aggrandizement. This has had a significant spill over effects in the management of IDPs, where the victims are starved to hunger, lack of proper medical care, poor education accessibility and serial raping and unwanted pregnancies.

\section{Conceptual Clarification State}

There exists no universally adoptable definition of the state, it has been dissected and viewed by in divergent ways; employing different perspectives. This has resulted in a plethora of different definitions. The State is largely an unavoidable human contraption for managing interpersonal, group and societal relationships. Meanwhile, numerous synoptic conceptions of the state abound in social science literature. Ladan (2013) defines the historic state as "a territorial human society which exercises, through a government, supreme coercive power over individuals and groups within it for regulating and maintaining a general hierarchy of social values and institutions". That State is a community of persons more or less numerous, permanently occupying a definite portion of territory, independent of external control, and possessing an organized government to which the great body of inhabitants render habitual obedience.

However, the nature and character of the Nigerian State has been suffering from post - colonial reductionism which accounts for the incessant conflicts (BH insurgence) she is experiencing; implicat- ing on the rising incidence of IDPs in North East, Nigeria. Alavi and Ake gave a thorough analysis, although, there are other scholars (Smith, 2009; Goulbourn,1979; Osaghae, 2005; Nzongola-Ntalaja, 1999; Beall \& Hassim, 2005) who have come up with divergent perspectives and descriptions to the same analysis of the African state, but in terms of the adequate investigations of the African state from its roots, i.e. colonialism being responsible for the conditions of the post-colonial state, both Alavi and Ake stand logically and highly pertinent. Alavi (1972) argues that the post-colonial state is the product of "the historical specificity which arises from structural changes brought about by the colonial experience and alignments of classes and by the super structures and alignments of classes and the super structures of political and administrative institutions which were established in that context and secondly from radical realignments of class forces which have been brought about in the post-colonial situation."

The escalation and dominance of the Boko Haram (BH) insurgency in Northeast Nigeria, has been largely attributed to the weak and ineffective control of the Nigerian state. In short, it is not out of place to posit that owing to the weak institutional structures and framework the Nigerian State inherited, there has been minimal control of the activities of sophisticated insurgents such as Boko Haram.

To that end, the Boko Haram insurgency and armed violence have continued to pose a colossal challenge to the Nigerian State. This has implicated in the rise of internally displaced persons (IDPs) in the country, particularly in the North East.

\section{Insurgency}

In the words of Kilcullen (2006), "Insurgency is a struggle to control a contested political space, between a state and (a group of states or occupying powers), and one or more popularly based, non- 
state challengers". Kilcullen also tried to draw a line between classical and contemporary insurgencies thus: "while the latter seek to replace the existing order, the former sometimes strive for the expulsion of foreign invaders from their territory or seek to fill an existing power vacuum" (Kilcullen 2006).

Similarly, the Oxford English Dictionary defines insurgency as "an armed rebellion against a constituted authority (for example, an authority recognized as such by the United Nations) when those taking part in the rebellion are not recognized as belligerents." According to this definition, "an insurgent is one who rises in revolt against constituted authority; a rebel who is not recognized as a belligerent." More so Insurgency according to Imasuen (2015), is a struggle to control a contested political space, between a state (or a group of states or occupying powers), and one or more popularly based, non-state challengers.

\section{Internally Displaced Persons (IDPs)}

The issue of internal displacement gained international limelight in the early 1990s. During its early discuss, scholars sought to make a clear distinction between refugees and internally displaced persons. In highlighting an essential feature, Cohen (1994) noted that unlike refugees, IDPs often fall within a vacuum of responsibility within their countries.

Elucidating further, Cohen (1995) opined that the distinction between IDPs and refugees can be best distinguished from the 'internal-external' angles of displacement. The International Legal Association (ILA) introduced a set of Guiding Principles and defined IDPs as follows: "persons or groups of persons who have been forced or obliged to flee or to leave their homes or places of habitual residence, in particular as a result of or in order to avoid the effects of armed conflict, situations of generalized violence, violations of human rights or natural or human -made disasters, and who have not crossed an internationally recognized State border" (IDP-Guiding Principles, 1998).

Ladan (2006) posits that globally and according to international laws, IDPs are regarded to as persons or groups of persons who have been forced or obligated to flee or to have cause to leave their homes or place of habitual residence in particular, owing to the effect of armed conflict, violations of human rights, religious violence, natural or man-made disasters, among others to another place considered relatively safe either within their own national borders. The emphasis here is that so long as the affected person that fled for safety are within the ambits of their countries and have not left the borders. In situations of armed conflict, IDPs, like any other person benefits from international humanitarian law, legal protection of international human rights, provisions of relief funds, materials etc to aid the IDP victims in camp and to further facilitate their rehabilitation and repatriation.

Regrettably, the Nigerian State have failed in both sides. On one side the Nigerian government failed to tackle effectively the Boko Haram insurgents that have continued to pose a threat to the inhabitants of North East and on the other hand failed to manage the displaced persons because of the insurgency.

\section{RESEARCH METHODS}

The study in its utmost, focused on the qualitative method in solving and providing analytical basis to the understanding and appreciation of the matter investigated. In its quest for empiricism, the paper made use of secondary methods of data collection and were systematically analyzed bearing the contents of the study in mind. Statistical data and graphs adopted were quite enormous and adequately analyzed. 
Available Online at http://journal.unismuh.ac.id/index.php/otoritas

Otoritas : Jurnal Ilmu Pemerintahan, 7 (2), October 2017, 88

\section{RESULT AND DISCUSSION}

\section{The Nigerian State Ineffective Control of Boko Haram Insurgency and Rising Incidence of IDPs in the North East}

Boko Haram terrorist attacks on individuals and physical assets that started on a lighter scale eight years ago have snowballed into a serious crisis, culminating in the declaration of emergency rule in three North-Eastern States of Borno, Yobe and Adamawa on 14 May 2013. Since Boko Haram began its campaign of terror against the Nigerian state, several people have been forced to flee their homes for areas safety in the sates of Amawa, Bauchi, Borno, Gombe, Taraba, and Yobe.

The Figure 1, shows how Boko Haram have been growing in influence since 2009, however, the ineffective control by the Nigerian State have only contributed to continued increase in the insurgency attacks in the North East. The implication of this increasing armed violence is the rise in the incidence of IDPs in the North East. The Nigerian government has also been criticised for its security forces lack presence and their ineffectiveness, this has in turn led to the formation of state vigilante groups which started in Borno state and later spread to other states in the region. It was subsequently officially recognised as the Civilian Joint Task Force (C-JTF).
The Nigerian Army dominates security services in the North-east region and before the coming of the President Buhari administration in 2015, suffered low morale, poor leadership and incompetence. The Amnesty International News (2014) reported that the Nigerian authorities had prior notice four hours before, of a possible attack on Chibok, a rural town in Borno State but regrettably proactive measures were not taken to reinforce security personnel to forestall any unpleasant outcome which subsequently resulted in the biggest single incident abduction of over 200 girls from Government Girls Secondary School Chibok.

The plight of internally displaced persons in Nigeria is worrisome given the inadequate security arrangements within the affected territories, communities and camps. Furthermore, in combating the Boko Haram insurgents the use of excessive force and live ammunitions by the Nigerian military has resulted in a sizeable number of killings which in turn caused widespread fear, anxiety and displacement (Human Rights Watch, 2012). Soldiers have also evicted displaced persons taking shelter in public buildings and converted such facilities for military purposes (Human Rights Watch, 2014).

From the above diagram, it has been empirically verified that the escalated Boko haram conflict in Nigeria is high in the North East, as seen Borno which has

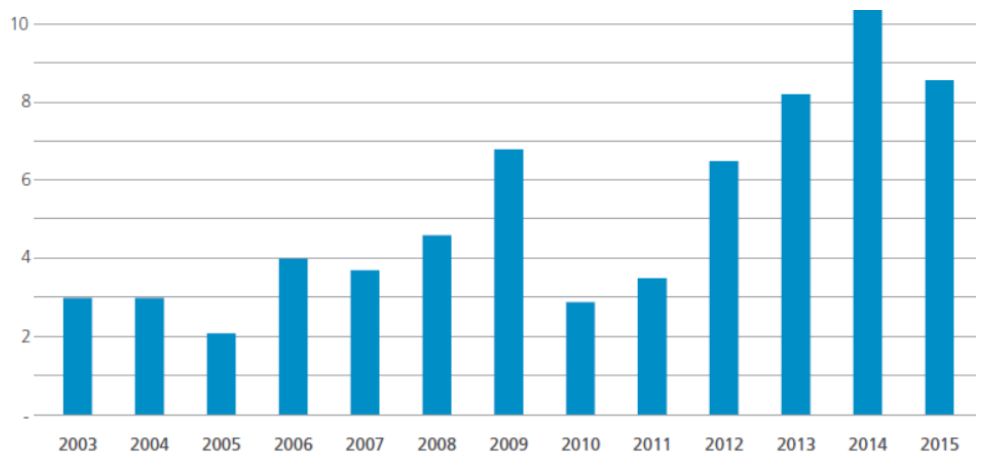

Figure 1. Rising and Uncontrolled Boko Haram attacks in North East, Nigeria Source: Segun \& Muscati (2014) 
Available Online at http://journal.unismuh.ac.id/index.php/otoritas

Otoritas : Jurnal Ilmu Pemerintahan, 7 (2), October 2017, 89

the highest number of IDP per individual and household within the region. However, it has justified that the ineffectiveness of the State to control the crisis is implicated in the rise of IDPs in North East region of Nigeria.

\section{Challenges Constraining the Effective Management and Rehabilitation of IDPs in North East, Nigeria}

Olagunju (2006), revealed that one of the major challenges constraining the effective management and rehabilitation of IDPs in North East, Nigeria, is that both federal and local governments in Nigeria have failed to put in place adequate machinery to address IDPs issues. He observed in line with other scholars that non-availability of required United $\mathrm{Na}$ tions Organisation (UNO) provisions in the country, most especially as it relates to the rehabilitation of the IDPs, which is on humanitarian grounds, can be traceable to lackluster attitude of Nigerian leaders. The alarming situation of temporary camps for the displaced persons in Nigeria is seen by majority as a manifestation of the various ills of mal-governance in the state.

He argued that the lackluster attitude of government was because of poor governance, lack of responsive political leadership, poor institutionalization of democratic governance and endemic institutional corruption. Most times, some of the materials meant for the IDPs are diverted for selfish interest. Onanuga (2013) noted further that about 22 camps are now established in the North East geopolitical zone, most of which are temporary camps. This shows that Nigerian government has failed to plan for permanent camps with necessary facilities. Furthermore, Daudu (2010) observed that the lack of protection of IDPs and the difficulties they encounter in reintegrating into the society has resulted in a situation whereby the Nigerian state feels threatened and undermined by the IDP generating phenomena. More important-

Table 1. Number of IDP Individuals and Households in Nigeria Source: IOM (2016)

\begin{tabular}{llll}
\hline \multicolumn{1}{c}{ IDP Locations } & \multicolumn{1}{c}{ IDP Individuals } & \multicolumn{1}{c}{ IDP Households } & Average HHs size \\
\hline Abuja & 15,154 & 2,510 & 6 \\
Adamawa & 132,626 & 19,636 & 6,7 \\
Bauchi & 65,365 & 10,442 & 6,3 \\
Benue & 85,850 & 11,150 & 7,7 \\
Borno & $1,525,404$ & 210,293 & 7,2 \\
Gombe & 26,233 & 4,752 & 5,5 \\
Kaduna & 40,688 & 5,687 & 7,1 \\
Kano & 11,853 & 2,315 & 5,1 \\
Nasarawa & 37,953 & 6,701 & 5,7 \\
Plateau & 68,365 & 12,226 & 5,6 \\
Taraba & 45,587 & 8,310 & 5,5 \\
Yobe & 139,550 & 31,908 & 4,4 \\
Zamfara & 46,856 & 8,678 & 5,4 \\
Grand total & $2,241,484$ & 334,608 & 6,7 \\
\hline
\end{tabular}


Available Online at http://journal.unismuh.ac.id/index.php/otoritas

Otoritas : Jurnal Ilmu Pemerintahan, 7 (2), October 2017, 90

ly, there is absence of clear cut policy, legal instruments and institutions to deal with pre and post displacement situations.

Corroborating the views of Onanuga, (2013) the initial challenge faced by the government in the Management of IDPs according to Itumo \& Nwobashi (2016) was the absence of legal and institutional frame responsible for providing short, medium and long-term measures in addressing the plights of the displaced persons. In the absence of a legal framework or institution, rehabilitation, reintegration and resettlement for IDPs is mostly undertaken by agencies of government on an ad-hoc and reactive basis, such as NEMA, SEMA, NCFRMI among others. However, there are myriads of problems that negatively affect IDPs management in $\mathrm{Ni}$ geria, e.g funding, corruption, overlapping functions of IDPs management institutions, dilapidated and unsecured camps etc. For this paper we shall focus on funding and corruption of government camp officials.

Osagioduwa \& Oluwakorede (2016) undertook a recent research survey and discovered that although IDPs management agencies in Nigeria get funds mainly through revenue from international aids and donations, yet the funds they get are often insufficient to meet the increasing needs of IDPs in the country. The concomitant effect of funds misappropriation is the deficiency in manpower, commodities, infrastructure, equipment and mobility. However, where there is paucity of funds, standard facilities will be unavailable, and the agencies will be inefficient.

On the other hand, corrupt office holders in government, and in IDPs management agencies alike, have been accused on several occasions diverting funds and relief materials meant for IDPs for their personal use and for their relatives or friends. A situation that reduces the efficiency of the agencies concerned in managing IDPs.

Cases of human trafficking, sex for food and gender based violence abound and has been widely reported in some camps. Human Rights Watch Report July (2016) documented sexual abuse, including rape and exploitation, of 43 women and girls living in seven internally displaced persons (IDP) camps in Maiduguri, the Borno State capital. The United Nations special rapporteur on the human rights of internally displaced personsChaloka Beyani, during his visit to Nigeria in August 2016 noted that the Nigerian government has a penchant for downplaying the problem of sexual violence and abuse of internally displaced persons.

In the effective management of IDPs, the following are recommended The country's foremost anti-corruption agency, the Economic and Financial Crimes Commission (EFCC) and other bodies

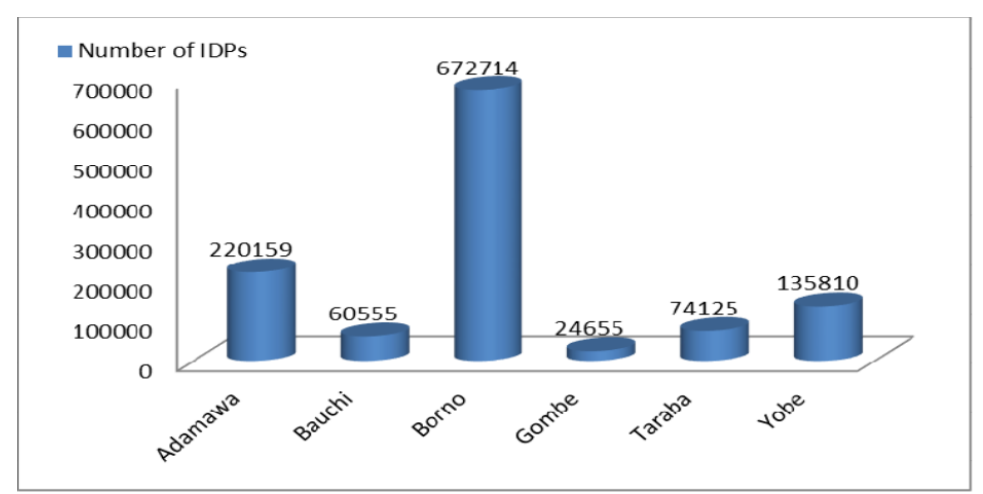

Figure 2. Histogram Showing the Number of IDPs in North East Source: Global Internal Displacement (2015) 
with similar mandate should prosecute everyone especially government officials, who has been fingered in the aid diversion scam. More fundamentally, the current SGF and every other person linked to the PINE contract scandal in the North East should be effectively prosecuted. Issues relating to human trafficking, recruitment of child soldiers, abuse of human rights and gender based violence should be thoroughly investigated and perpetrators should be brought to book in a fair and judicial manner.

The establishment of a government agency specifically designated to manage the affairs of displaced persons is paramount as it would check the duplication and overlapping of functions among commissions or emergency agencies as is presently the case. Strict measures must be undertaken to institutionalize accountability and transparency which constitutes key administrative ingredients for the effective management of displaced persons.

\section{CONCLUSION}

In Nigeria, particularly in the North East, the internally displaced persons are yet to be rehabilitated and resettled. As reported, $8 \%$ of IDPs lives in camps thereby making it possible for the insurgents to carry out direct physical attacks. It quintessential to note at this point that management of IDPs has not been an easy task especially in Nigeria that takes dominant position in IDPs management. is under the attack of Boko Haram insurgents. However, her inability to tackle and manage the after effects of terrorism in the North East continues to raise humanitarian concerns and which proves beyond all doubt that Nigeria is a weak state. On the contrary, NGOs and private bodies should collaborate with the government in the management of the IDPs to achieve the 3Rs.

\section{ACKNOWLEDGEMENT}

The authors are grateful to our colleague in Faculty of Political Science and Faculty of Philosophy, School of Social Sciences, University of Nigeria, Nsukka for the support and discussion that has been implemented to complete the writing of the article.

\section{REFERENCES}

Alavi, H. (1972). The state in post-colonial societies Pakistan and Bangladesh. New Left Review, (74), 59.

Amnesty International (2014). Nigerian authorities failed to act on warnings about Boko Haram raid on school. Retrieved 11 October 2016, from http:// www.amnesty.org/en/latest/ news/2014/05/nigerianauthorities-failed-act-warningsabout-boko-haram-raid-school/.

Table 2. Some Foreign and Local Donors' Funds for Northeast Development Source: Compiled from Odufowokan(2016)

\begin{tabular}{lll}
\hline S/N & \multicolumn{1}{c}{ Donors } & \multicolumn{1}{c}{ Amounts Donated } \\
\hline 1 & Dangote and other individuals & N6.3 billion \\
2 & World Bank & $\$ 800$ million \\
3 & UNDP & $\$ 248$ million [ $\$ 24$ million has so far been released] \\
4 & United States & $\$ 200$ million \\
5 & Saudi Arabia & $\$ 750$ million \\
6 & Australian Government & N900 million \\
\hline
\end{tabular}


Available Online at http://journal.unismuh.ac.id/index.php/otoritas

Otoritas : Jurnal Ilmu Pemerintahan, 7 (2), October 2017, 92

Cohen, R. (1995) Refugee and Internally Displaced Women: A Development Perspective. Washington DC: The Brookings Institution/ Refugee Policy Group Project on Internal Displacement.

Cohen, R. (1994). International Protection for Internally Displaced Persons. Stud. Transnat'l Legal Pol'y, 26, 17.

Daudu, A. (2010). An Overview of the management of internally displaced persons in the United States of America and Nigeria. Retrived 2 August 2016, from http:// www.works.bepress.com/ benedictadaudu/1/.

Ekekwe, E. (1986). Class and State in Nigeria. Owerri: Longman Nigeria Limited.

Human Rights Watch (2016). Nigeria: Officials abusing displaced women, girls. Displaced by book haram and victims twice. Retrived 22 October 2016, from http://ww.hrw.org/ news/2016/10/31/nigeriaofficials-abusing-displacedwomen-girls.

Human Rights Watch (2014). Those Terrible Weeks in their Camp: Boko Haram Violence against Women and Girls in the Northeast Nigeria. Retrived October 2016,from http//www.hrw.org/features/ HRW_2014_report/ Those_Terrible_Weeks_in_Their_C amp/index.html.

Human Rights Watch (2012). Spiraling Violence: Boko Haram Attacks and Security Force Abuses in Nigeria. Retrived 20 September 2016, from http://www.hrw.org.

Imasuen, E. (2015). Insurgency and humanitarian crises in Northern $\mathrm{Ni}$ geria: The case of Boko Haram. African Journal of Political Science and International Relations, 9(7).
Itumo, A., \& Nwefuru, N. H. (2016). Nigerian State and Responses to Plights of Persons Internally Displaced by Boko Haram Insurgents: Implications for Socio-Economic and Political Development. Research on Humanities and Social Sciences, 6 (15), 24-38.

Kilcullen, D. (2006). Counter-insurgency redux. Survival, 48(4), 111-130.

Ladan, M. T. (2012, May). Impact of insecurity in the north on internally displaced people and migration flows between Nigeria and neighbouring countries. In Being a Paper Presentation made at the Forum of European Union Working Group in Nigeria and Development, Abuja.

Obikaeze, V., and Onuoha C., (2016) The Nigeria-State and Management of Internally Displaced Persons (IDPs) from 2012-2016. Africa Journal of Politics and Society, 6 (1),12-24.

Odufowokan, D. (2016). IDPs: Where are the donor funds? The Nation. Retrived 12 December 2016, from http://thenationonlineng.net/ idps-donor-funds/.

Onanuga, A. (2013). "How Jonathan can combat security crisis". The Nation Newspaper,May 14(24-30).

Osagioduwa, E. and Oluwakorede, O.T. (2016). Management of internally displaced persons in Africa: Comparing Nigeria and Cameroon. African Research Review, 10(1), 193210.

Segun, M., \& Muscati, S. (2014). 'Those terrible weeks in their camp': Boko Haram violence against women and girls in Northeast Nigeria. 